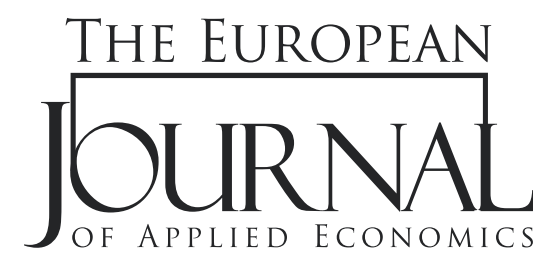

EJAE 2020, 17(1): $113-127$

ISSN 2406-2588

UDK: $339.56(519.3)$

339.982(100)

DOI: 10.5937/EJAE17-24702

Original paper/Originalni naučni rad

\title{
AN ANALYSIS OF NORTH KOREAN TRADE AMID WARMING GLOBAL RELATIONS UTILIZING RCA, RSCA, AND TBI
}

\author{
Aaron Rae Stephens*, Ramin Kasamanli \\ Department of Business Administration and Accounting, \\ Hartwick College, \\ Oneonta, NY, USA
}

\begin{abstract}
:
Based on high profile meetings with South Korean and US leaders, North Korean denuclearization and global economic cooperation is within sight. This paper seeks to outline trade policy opportunities for North Korea given such breakthroughs. This research summarizes international trade in North Korea and identifies sectors of the economy that are poised to further develop the North Korean economy. Employing three measures of trade specialization - RCA, RSCA, and TBI, this paper analyzes time series trade data from 2011 to 2018 in order to reveal specialized export sectors in North Korea. Chinese and UN bans on exports have been particularly damaging to exports from North Korea based on 2018 data. North Korea has comparative advantages in several sectors: coal, fisheries, and apparel among other areas. Trade in North Korea would lead to rapid industrialization and development if the country opens its economy; a well-managed approach would serve to direct development in specific sectors without sacrificing others; moreover, this research advises which sectors can be used to develop North Korea in an early stage of openness.
\end{abstract}

\section{Article info:}

Received: January 7, 2020

Correction: February 18, 2020

Accepted: February 20, 2020

\section{Keywords:}

North Korea, international trade,

RCA,

RSCA,

TBI.

\section{INTRODUCTION}

North Korea remains one of the most secretive and least understood countries in the world today; hence, one of its common nicknames, the Hermit Kingdom. Despite the inherent challenges, scholars must find creative ways to study North Korea. Many studies break through those constraints and manage to publish meaningful research regarding North Korea. 
This paper reviews some of the distinguishing economic changes taking place inside North Korea through a literature review, and connects that to an econometric analysis of the licit economic trade that takes place between North Korea and other countries throughout the world. The results of this research are designed to provide a framework for future studies, policymakers, and trade practitioners interested in North Korea.

In spite of many complex sanctions blocking trade, licit trade does take place; moreover, understanding that trade should help policymakers to understand how the North Korean economy could develop better trade relations if it were to change course and further integrate into the international community. Considering North Korea has improved its relationship with the US and neighboring nations (Jo, 2019), it is now more appropriate than ever before to conduct this kind of study to prepare a framework for future studies regarding North Korean trade.

There has been a longstanding public display of disagreement between the global community and North Korea, especially regarding nuclear proliferation (BBC, 2017). This disagreement nearly boiled over in 2017 before rapid de-escalation in 2018 through a series of meetings, negotiations, and summits that began during the 2018 Winter Olympics in Pyeongchang, South Korea; however, South Korean agreements have outpaced US North Korean talks (Jo, 2019). The two Koreas have continued on a path towards peace and cooperation (The Japan Times, 2019; Song and Kang, 2019). South Korea is keenly interested in developing longstanding peace on the Peninsula; indeed, this could have lasting benefits to the South Korean economy with respect to regional stability and the financial markets alone (Dibooglu and Cevik, 2016), and perhaps more important, long-term cooperative economic growth (Kim, 2019; Song and Kang, 2019).

Reunification is frequently the subject of many papers studying North Korea (Grzelczyk, 2014); however, it seems that reunification is no longer the desire of most South Koreans (Ha and Jang, 2016). Moreover, a two state solution with trade and economic cooperation at the center is more in line with the sentiments of South Korean's today; thus, it is relevant to look at reunification through the lens of trade and economic cooperation.

Many South Korean entrepreneurs are eager to develop labor, mineral resources, and other business opportunities should the political landscape allow it (Kim, 2019, Song and Gang, 2019). The South Korean government, bureaucrats and entrepreneurs have struggled to speed up Korean economic growth; moreover, they see North Korea as an opportunity for future growth, with its cheaper labor and abundant raw materials (Kim, 2019; Song and Gang, 2019). Youth unemployment and other demographic issues have exacerbated the concerns of South Korean policymakers and business practitioners alike, highlighting the potential benefits of economic cooperation with North Korea (The Japan Times, 2019). Understanding the trade situation in North Korea before deeper economic integration between the two Koreas should be an imperative before further integration. This paper provides an inaugural framework for future trade and economic cooperation between the two Koreas and the world.

This study is designed to map out the latest trade scenario and identify comparative trade advantages of North Korean goods; then provide important policy and practitioner implications in order to guide future trade in North Korea.

This research employs several methodologies to describe the international trade scenario for North Korea, including: top exports and imports, top import and export nations, and specialized sectors. This paper is divided into several sections; first, a literature review that is divided into four parts, including trade specialization, North Korean political economy, trade in North Korea, and inter-Korean cooperation. 
After the literature review, several trade measures are utilized to measure comparative advantage in order to identify strong economic sectors for trade, including the Balassa Index, the symmetrical revealed comparative advantage, and the trade balance index, also known as the Lafay Index. The methodology section describes each method and its utilization. Following the methodology is the analysis section, which reports on the results of the research with a discussion of the implications. Finally, the conclusion summarizes the contributions, touches on the limitations, and highlights possible future studies.

\section{THEORETICAL UNDERPINNINGS AND NORTH KOREAN TRADE}

Multiple prominent theories explain trade specialization between nations: the absolute advantage theory by Adam Smith (1776), the comparative advantage theory proposed by David Ricardo (1817), the factor endowment theory defined by Heckscher-Ohlin (1925), and the competitive advantage theory articulated by Porter (1980). Each theory builds on a broader understanding of trade specialization and why countries conduct international trade. Absolute advantage theory argues that a country exports a product because it is simply the best producer in a particular sector; however, countries continue to trade products without a single country dominating all trade; moreover, many exports do not maintain clear absolute advantages. Absolute advantage theory lacks the ability to describe how countries that do not have an absolute advantage in a particular sector continue to specialize in such sectors.

Ricardo's theory of comparative advantage theory utilizes opportunity costs to explain how a sector can export while not maintaining an absolute advantage. Heckscher-Ohlin (1925) built on Ricardo's theory to explicate the details of how comparative advantage is created through factor endowment theory; moreover, differences in factors of production between countries lead to different opportunity costs, which lead to specialization in different sectors. For decades, comparative advantage theory was used to explain trade at a national level. Porter (1980) focused on industry-based factors that lead to export specialization within specific industries. Previous theories focused on country-level phenomena while Porter looked at industry-level phenomena to describe trade specialization. There are inherent advantages to utilizing each theoretical framework for describing trade specialization; however, it is notably challenging to examine North Korean firms at the industry-level. North Korean industries remain closed to outsiders; thus, out of reach for any firm-based study. Considering the constraints of studying North Korean firms, trade specialization must be examined at the country-level where data is attainable. Comparative advantage theory remains the basis of establishing trade specialization today, and three methods are utilized to measure it: RCA, RSCA, and TBI (Laursen, 2015; Lafay, 1990); the methods are further described in the methodology.

North Korea has been termed a theater state wherein politics are both performative and performed; moreover, many aspects of the economy play a role in those performances (Kwon and Chung, 2012; Winstanley-Chesters, 2018). When studying North Korea, it is imperative to understand its performance-based political economy (Kwon and Chung, 2012). Other scholars have found it necessary to comprehend the NK political economy in this manner in order to frame a theoretical understanding of its political economy, including Winstanley-Chesters (2018) and Connell (2019). According to Winstanley-Chesters (2018), North Korea is a resource-rich country with a great variety of minerals and metals; however, the exploitation and trade of those resources is highly guarded and closely managed by the autocratic government of North Korea in a theatric manner. Connell (2019) frames North Korean tourism as a political theater. 
Considering the corrupt and unusual context of North Korea's political economy, it is necessary to utilize this unique theoretical underpinning of the theater state in order to understand its political and economic behaviors; indeed, much of what is done in North Korea is through the façade of socialism and saving international face.

Lately, the North Korean economy has experienced internal growth that has been driven by internal market forces, including entrepreneurialism compelled by women; this is in part because of economic failures from the mid-1990s (Jung et al., 2018). Marketization was noted by a 2008 survey of North Korean defectors living in South Korea; 69\% of defectors claimed that more than half of their income was from private income (Haggard and Noland, 2010). Indeed, economic growth lately is in contrast to the fact that the North Korean economy shrank by as much as 30\% from 1991 to 1996 (Jung and Dalton, 2006); furthermore, it is estimated that between 600,000 to one million people died during that period because of famine (Haggard and Noland, 2009). Marketization of North Korea is the result of necessity; moreover, food and necessities are bought and sold in a private market in order to meet demands that are not met through the government-owned sectors (Haggard and Noland, 2010).

Table 1: Top Nations Receiving Exports from North Korea

\begin{tabular}{|c|c|c|c|c|c|c|}
\hline \multirow{2}{*}{ Importers: } & \multicolumn{2}{|c|}{$\underline{2012}$} & \multicolumn{2}{|c|}{$\underline{2015}$} & \multicolumn{2}{|c|}{$\underline{2018}$} \\
\hline & $\underline{\text { Exports }}$ & Percent & $\underline{\text { Exports }}$ & $\underline{\text { Percent }}$ & Exports & Percent \\
\hline TOTAL & $3,156,495$ & $100 \%$ & $3,059,350$ & $100 \%$ & 293,932 & $100 \%$ \\
\hline China & $2,502,531$ & $79 \%$ & $2,567,685$ & $84 \%$ & 213,208 & $73 \%$ \\
\hline Zambia & 1,611 & $0 \%$ & 13,919 & $0 \%$ & 20,090 & $7 \%$ \\
\hline Mozambique & 3,462 & $0 \%$ & 10,579 & $0 \%$ & 9,212 & $3 \%$ \\
\hline Pakistan & 52,285 & $2 \%$ & 45,730 & $1 \%$ & 7,379 & $3 \%$ \\
\hline Ghana & 461 & $0 \%$ & - & $0 \%$ & 6,152 & $2 \%$ \\
\hline India & 137 & $0 \%$ & 99,006 & $3 \%$ & 4,844 & $2 \%$ \\
\hline Burkina Faso & 78 & $0 \%$ & 37,196 & $1 \%$ & 4,468 & $2 \%$ \\
\hline Fiji & 357 & $0 \%$ & 9,612 & $0 \%$ & 4,225 & $1 \%$ \\
\hline Nigeria & 34 & $0 \%$ & 10,754 & $0 \%$ & 3,932 & $1 \%$ \\
\hline
\end{tabular}

Export values are in US Dollar thousand.

Ironically, private enterprise is illegal; however, the government turns a blind eye to such practices and allows it out of necessity; furthermore, private enterprises are registered as state owned enterprises in order to maintain the façade (Lankov, 2017). Accordingly, international trade through private enterprise is also illegal; however, the government takes international trade more seriously (Haggard and Noland, 2010); trade is likely restricted in order to control trade in information and foreign currency. 
Table 2: Top Nations of Origin for Imports Entering North Korea

\begin{tabular}{lcccccc}
\hline \multirow{2}{*}{ Exporters: } & \multicolumn{2}{c}{$\underline{\mathbf{2 0 1 2}}$} & \multicolumn{2}{c}{$\underline{\mathbf{2 0 1 5}}$} & \multicolumn{2}{c}{$\underline{\mathbf{2 0 1 8}}$} \\
\cline { 2 - 7 } China & $\underline{\text { Imports }}$ & $\underline{\text { Percent }}$ & $\underline{\text { Imports }}$ & $\underline{\text { Percent }}$ & $\underline{\text { Imports }}$ & $\underline{\text { Percent }}$ \\
\hline Russia & $3,532,383$ & $82 \%$ & $2,942,917$ & $85 \%$ & $2,218,140$ & $96 \%$ \\
\hline India & 58,428 & $1 \%$ & 78,267 & $2 \%$ & 32,083 & $1 \%$ \\
\hline Brazil & 230,158 & $5 \%$ & 110,902 & $3 \%$ & 31,004 & $1 \%$ \\
\hline Switzerland & 2,428 & $0 \%$ & 2,482 & $0 \%$ & 7,287 & $0 \%$ \\
\hline Germany & 29,933 & $1 \%$ & 5,173 & $0 \%$ & 3,295 & $0 \%$ \\
\hline Colombia & - & $0 \%$ & 0 & $0 \%$ & 3,179 & $0 \%$ \\
\hline Mozambique & 969 & $0 \%$ & 227 & $0 \%$ & 2,075 & $0 \%$ \\
\hline Hong Kong & 57,009 & $1 \%$ & 4,988 & $0 \%$ & 1,600 & $0 \%$ \\
\hline Peru & 562 & $0 \%$ & 21,187 & $1 \%$ & 1,521 & $0 \%$ \\
\hline
\end{tabular}

Import values are in US Dollar thousand.

Trade with North Korea is not without extreme moral hazard; to begin with, its governance is responsible for the political incarceration of over 140,000 citizens in Soviet-style concentration camps, the execution of those opposing its policies, including foreign citizens outside of North Korea, and the indoctrination of its citizens (Salam and Haag, 2018). North Korea is globally considered a rogue nation for violating global nuclear nonproliferation agreements, which is substantiated by not only developing nuclear weapons, but also developing the means to deliver those weapons (Department of Defense, 2019). Global condemnation has resulted in numerous economic sanctions designed to punish the regime and encourage its compliance with nuclear non-proliferation; nevertheless, the country remains defiant and international trade continues, albeit, disturbed.

Despite a multitude of UN Security Council sanctions, trade in North Korea does continue. The country has an extensive trade relationship with China, its closest political and economic partner. This is not surprising, given China's proximity and history with NK; nevertheless, it is remarkable that in $2018,96 \%$ of North Korean imports came from China alone. That is up from 2012, when only $82 \%$ of its imports came from China. North Korean exports for the year 2018 are more diversely directed throughout the world: $72 \%$ of exports go to China, while an additional 15\% make it to five countries in Africa: $7 \%$ to Zambia, 3\% to Mozambique, 2\% to Ghana, 2\% to Burkina Faso, and 1\% to Nigeria. Pakistan received 3\% and India received $2 \%$ of North Korea's exports in 2018. According to the numbers, North Korea is slightly less dependent on China for its exports, and more dependent for its imports. Despite its dependence on China, imports from China fell by $88 \%$ in 2018, as China is putting more pressure on North Korea (Nagai, 2019).

Although Russia and North Korea are geopolitically aligned and share a border, trade between the two nations remains weak at \$34 million in 2018 (Snyder, 2019; Zakharova, 2016); nevertheless, Russia is North Korea's second largest trading partner (Lukin and Zakharova, 2018). A trade relationship between the two has been considered academically and politically; however, there are reasons the two nations do not have better trade relations: one Russia's border with NK is remotely populated and two financial sanctions make trade with North Korea difficult (Lukin and Zakharova, 2018). During the era of the Soviet Union, North Korea relied on Russian/Soviet imports to prop up its economy; after the fall of the Soviet Union, Russia focused on redeveloping its own economy, thereby neglecting North Korea (Zakharova, 2016). Perhaps geopolitical influences may change the Russia-North Korea trade relationship, but thus far it remains marginalized. 
Table 3: Top Exports

\begin{tabular}{|c|c|c|c|c|c|c|}
\hline \multirow{2}{*}{$\underline{\text { Code }}$} & \multicolumn{2}{|c|}{$\underline{2012}$} & \multicolumn{2}{|c|}{$\underline{2015}$} & \multicolumn{2}{|c|}{$\underline{2018}$} \\
\hline & $\underline{\text { Exports }}$ & Percent & Exports & Percent & $\underline{\text { Exports }}$ & Percent \\
\hline 72 & 158,004 & $5 \%$ & 93,473 & $3 \%$ & 35,274 & $12 \%$ \\
\hline 91 & 191 & $0 \%$ & 43 & $0 \%$ & 31,347 & $11 \%$ \\
\hline 84 & 107,294 & $3 \%$ & 54,870 & $2 \%$ & 26,270 & $9 \%$ \\
\hline 26 & 358,493 & $11 \%$ & 204,743 & $7 \%$ & 25,371 & $9 \%$ \\
\hline 67 & 707 & $0 \%$ & 928 & $0 \%$ & 24,178 & $8 \%$ \\
\hline 99 & 719 & $0 \%$ & 75,824 & $2 \%$ & 18,798 & $6 \%$ \\
\hline 90 & 9,619 & $0 \%$ & 10,566 & $0 \%$ & 13,154 & $4 \%$ \\
\hline 27 & $1,347,342$ & $43 \%$ & $1,160,136$ & $38 \%$ & 12,770 & $4 \%$ \\
\hline 39 & 35,585 & $1 \%$ & 31,062 & $1 \%$ & 10,909 & $4 \%$ \\
\hline 25 & 48,796 & $2 \%$ & 47,207 & $2 \%$ & 10,552 & $4 \%$ \\
\hline
\end{tabular}

Export values are in US Dollar thousand.

Exports by sector for 2018 remain more diverse: sector 72, iron and steel, made up 12\% (mostly ferrous alloys), sector 91, clocks, watches, and parts thereof made up 11\%, sector 84 , (primarily items from code 8477 : machinery for working rubber or plastics) made up $9 \%$, sector 26 , ores, slag, and ash, made up $9 \%$, and sector 67 , feathers and down, made up $8 \%$ of exports out of North Korea. Additionally, exports that do not fit into any particular sector made up 6 percent, while sectors 90 (primarily category 9023: instruments, apparatus, and models deigned for demonstrational purposes, e.g., in education), 27 (primarily coal), 39 (plastics going to China and Africa) and 25 (mostly graphite and magnesium carbonate) each made up $4 \%$ of exports (trademap.org). Sector 27 , associated primarily with coal, was an important sector for North Korean exports; based on the data, $43 \%$ of their exports were coal-based exports in 2012. Coal imports from NK were halted by China in February 2017 in order to put greater pressure on North Korea (Denyer, 2017).

Table 4: Top Imports

\begin{tabular}{|c|c|c|c|c|c|c|}
\hline \multirow{2}{*}{$\underline{\text { Code }}$} & \multicolumn{2}{|c|}{$\underline{2012}$} & \multicolumn{2}{|c|}{$\underline{2015}$} & \multicolumn{2}{|c|}{$\underline{2018}$} \\
\hline & Imports & $\underline{\text { Percent }}$ & $\underline{\text { Imports }}$ & $\underline{\text { Percent }}$ & Imports & Percent \\
\hline 39 & 142,036 & $3 \%$ & 175,047 & $5 \%$ & 221,167 & $10 \%$ \\
\hline 15 & 81,213 & $2 \%$ & 106,651 & $3 \%$ & 159,988 & $7 \%$ \\
\hline 54 & 129,980 & $3 \%$ & 152,043 & $4 \%$ & 138,384 & $6 \%$ \\
\hline 31 & 69,999 & $2 \%$ & 19,673 & $1 \%$ & 84,780 & $4 \%$ \\
\hline 8 & 16,164 & $0 \%$ & 60,165 & $2 \%$ & 82,499 & $4 \%$ \\
\hline 60 & 49,509 & $1 \%$ & 75,453 & $2 \%$ & 80,649 & $3 \%$ \\
\hline 61 & 66,428 & $2 \%$ & 98,401 & $3 \%$ & 74,670 & $3 \%$ \\
\hline 3 & 48,804 & $1 \%$ & 102,988 & $3 \%$ & 71,943 & $3 \%$ \\
\hline 24 & 66,328 & $2 \%$ & 41,458 & $1 \%$ & 71,359 & $3 \%$ \\
\hline 11 & 73,633 & $2 \%$ & 21,142 & $1 \%$ & 68,279 & $3 \%$ \\
\hline
\end{tabular}

Import values are in US Dollar thousand. 
South Korean investors are eager to develop better trade relations with North Korea to capture opportunities (Kim, 2019). The South Korean economy shrank for the first quarter of 2019, putting pressure on the current president Jae In Moon to develop better economic prospects for his constituents (Song and Kang, 2019; Kim, 2019 ). Moon has been relatively soft on North Korea in an effort to develop better economic ties and even open the North Korean economy to South Korean business interests (Song and Kang, 2019). North Korean economic prospects are appealing to South Korean businesses; however, they are also quite risky; investments have proven to be risky to many businesses, even turning them away to future ventures (Kim, 2019).

The Kaesong Industrial Complex (KIC) is a well-known inter-Korea cooperative industrial complex that has gained international attention primarily because of its conflicting position as both an enabling agent of the North Korean regime and as a means of coaxing the regime out of isolation and towards inter-Korean cooperation. Given the geopolitical and economic significance of Kaesong, it is important to weigh its position in North Korean trade. According to data collected by Manyin and Nanto (2010), the KIC at its peak employed 47,000 North Korean employees; hosted 121 Korean firms: 71 textile or apparel firms, 4 kitchen and utensil firms, 4 auto parts firms, 2 semi-conductor firms, and 1 printer toner firm among others. Sadly, the average monthly income for one North Korean worker in 2010 was only \$35 a month after the regime took its share; furthermore, production in 2010 was around $\$ 323$ million; thus, Kaesong exports amounted to $10 \%$ of all North Korean exports that year (Manyin and Nanto, 2010). Since 2010, the South Korean government scaled back punitively in retaliation for aggressions against the South.

\section{METHODOLOGY}

Revealed comparative advantage (RCA) was first proposed to measure comparative advantage in Balassa (1965). The equation and methodology illustrated in Figure 1 is touted as an easy-to-apply method for measuring comparative advantage; however, it is significantly limited by a lack of mathematical symmetry with regard to results (Yeats, 1985; Vollrath, 1991); nevertheless, it remains a steadfast measure of export specialization (French, 2017). It is utilized by multiple global institutions to measure trade specialization including the United Nations and the OECD, among others (UNIDO, 1986; OECD, 2011). Hinloopen and Marrewijk, (2008) provide detailed guidance on measuring the level of comparative advantage afforded to an export sector while utilizing RCA; moreover, results indicate varying degrees of comparative advantage based on specified intervals: an RCA between 0 - 1 indicates no comparative advantage; 1-2 indicates a weak comparative advantage; 2-4 indicates a moderate advantage, and an RCA over four indicates a strong comparative advantage. Considering the simplicity of RCA, its ubiquity in trade specialization studies, and its ability to indicate varying levels of advantage, this study adopts the RCA as a methodology for analysis.

$$
R C A^{D P R K}=\left(x_{i}^{D P R K} / x^{D P R K}\right) /\left(x_{i}^{W L D} / x^{W L D}\right)
$$

Despite years of persistent use, RCA is pointedly limited by mathematical symmetry (Yeats, 1985; Vollrath, 1991); thus, it is frequently coupled with RSCA, a mathematically symmetrical measure of RCA. With a symmetrical measure of trade specialization, it is possible to examine advantages and disadvantages on congruent terms; values above 0 are considered a comparative advantage, while values below 0 are considered comparative disadvantages; the bounds are limited to 1 and -1 . 


$$
R S C A^{D P R K}=\left(R C A^{D P R K}-1\right) /\left(R C A^{D P R K}+1\right)
$$

\section{Lafay Index}

Lafay (1990) describes the trade balance index (TBI) as an alternative methodology for measuring trade specialization utilizing import data, as well as export data. A noted deficiency of RCA and RSCA is the sole use of export data to establish trade specialization; ultimately, a better-rounded picture of trade specialization includes both imports and exports (Lafay, 1990); therefore, TBI has been adopted for another means of analysis.

$$
\text { Lafay }_{i}=K *\left[\left(x_{i}^{D P R K}-M_{i}^{D P R K}\right)-\left(x^{D P R K}-M^{D P R K}\right) *\left(\frac{\left(X_{i}^{D P R K}+M_{i}^{D P R K}\right)}{\left(X^{D P R K}+M^{D P R K}\right)}\right)\right]
$$

One study by Rossato et al. (2018) combined the three indices (RCA, RSCA and TBI) together in order to analyze a single export sector in multiple countries. Another study by Reyes 2014 used RCA and TBI to analyze multiple sectors among a group of countries. The combination of methodologies serves to corroborate and diversify the findings by using established methods and a variety of data points (export and import data); moreover, utilizing three methodologies creates a broader and more holistic image of trade specialization.

Due to increased international pressure to curb North Korean denuclearization, trade was greatly restricted through sanctions and bans from late 2017: i.e., bans on food exports, China's ban on coal imports from North Korea, and the UN's ban on textiles from North Korea; thus, data in 2018 cannot represent export specialization in North Korea. Indeed, data from many sectors was greatly distorted based on a review of 2018 exports and imports; thus, it was decided that, for this study, 2017 data would provide the best indication of trade specialization without the latest set of bans affecting the analysis. All countries are artificially affected by trade barriers similarly to North Korea, yet these trade methodologies are utilized to give valid results globally; thus, it is acceptable to use these methods with such limitations duly noted.

\section{ANALYSIS}

Industries maintaining comparative advantages increased from 2011 to 2017; only 11 industries exhibited a comparative advantage in 2011, while 14 industries exhibited a comparative advantage in 2017. Furthermore, some sectors improved their comparative advantage, indicating positive economic changes in North Korea. The most remarkable comparative advantages and changes over time are noted in this analysis. Comments on each remarkable sector as evidenced by the data are linked back to literature in order to fully depict the situation in each sector. Finally, the analysis is brought full circle towards theory, such that discrepancies are considered for additional theoretical contributions.

A strong comparative advantage in fisheries (code 03) increased from an RCA of 4.6 in 2011 to 12.5 in 2017; moreover, a comparative advantage is corroborated in the other two indices. A comparative advantage in fisheries likely exists because fishing rights in North Korea were sold to Chinese fishing companies in order to make up for insufficient North Korean capital (primarily ships and equipment) 
(Ma, 2017; Shimbun, 2019). Unfortunately, such exports likely do not come back to benefit the average North Korean citizen; the fishing rights were granted by the state, and the income is retained by the state for the benefit of its autocracy (Shimbun, 2019).

Some food stuffs displayed a comparative advantage, which is unexpected considering frequent news coverage of famine in North Korea. Nuts (code 8) held a weak comparative advantage (RCA 1.6) in 2011, but improved to a strong comparative advantage (RCA 5.9) by 2017; according to data at trademaps.org, most nuts were sent to China. The quantity of nut exports peaked in 2014, but North Korea gained a greater comparative advantage through 2017. Other foods (code 7 and 12) exhibited weak comparative advantages in 2017 (RCA 1.6 and 1.3 respectively). Food exports from North Korea were banned December 22, 2017 by UN resolution 2397 (UN.org); thus, data collected in 2018 would be unlikely to reveal any natural comparative advantages.

Table 5: Results of the Analysis

\begin{tabular}{|c|c|c|c|c|c|c|c|c|c|}
\hline \multirow{2}{*}{ Code } & \multicolumn{3}{|c|}{2011} & \multicolumn{3}{|c|}{2014} & \multicolumn{3}{|c|}{2017} \\
\hline & BI & RSCA & TBI & BI & RSCA & TBI & BI & RSCA & TBI \\
\hline 3 & 4.653 & 0.646 & 7.652 & 7.282 & 0.759 & 11.392 & 12.465 & 0.851 & 24.601 \\
\hline 7 & 0.237 & -0.617 & -0.222 & 0.914 & -0.045 & 0.589 & 1.604 & 0.232 & 2.192 \\
\hline 8 & 1.665 & 0.250 & 2.786 & 5.842 & 0.708 & 11.152 & 5.988 & 0.714 & 10.065 \\
\hline 12 & 0.786 & -0.120 & -0.745 & 0.803 & -0.109 & 0.754 & 1.266 & 0.117 & 2.909 \\
\hline 25 & 8.821 & 0.796 & 7.708 & 5.774 & 0.705 & 4.910 & 9.752 & 0.814 & 9.897 \\
\hline 26 & 8.338 & 0.786 & 46.063 & 8.233 & 0.783 & 45.458 & 8.393 & 0.787 & 43.510 \\
\hline 27 & 2.102 & 0.355 & 79.972 & 2.207 & 0.376 & 147.718 & 1.988 & 0.331 & 83.524 \\
\hline 36 & 0.000 & -1.000 & -0.001 & 0.281 & -0.562 & 0.033 & 0.524 & -0.312 & 0.038 \\
\hline 46 & 0.796 & -0.114 & 0.053 & 0.352 & -0.479 & 0.020 & 0.525 & -0.311 & 0.021 \\
\hline 49 & 0.129 & -0.771 & 0.116 & 0.298 & -0.540 & 0.319 & 0.123 & -0.780 & 0.097 \\
\hline 50 & 2.313 & 0.396 & 0.165 & 2.129 & 0.361 & 0.132 & 0.919 & -0.042 & 0.050 \\
\hline 61 & 1.514 & 0.204 & 1.743 & 2.793 & 0.473 & 3.287 & 2.636 & 0.450 & 0.287 \\
\hline 62 & 10.982 & 0.833 & 58.637 & 15.311 & 0.877 & 88.762 & 19.887 & 0.904 & 113.064 \\
\hline 67 & 0.544 & -0.296 & -0.091 & 0.467 & -0.363 & -0.006 & 10.494 & 0.826 & 0.975 \\
\hline 71 & 0.027 & -0.947 & 0.453 & 0.319 & -0.517 & 5.039 & 0.013 & -0.974 & 0.118 \\
\hline 72 & 2.312 & 0.396 & 16.799 & 1.808 & 0.288 & 5.791 & 1.972 & 0.327 & 7.845 \\
\hline 74 & 0.200 & -0.666 & -0.599 & 0.626 & -0.230 & 1.791 & 0.063 & -0.881 & -1.084 \\
\hline 75 & 0.313 & -0.523 & 0.177 & 0.113 & -0.797 & 0.082 & 0.020 & -0.961 & 0.004 \\
\hline 78 & 1.310 & 0.134 & 0.217 & 1.660 & 0.248 & -0.806 & 3.190 & 0.523 & 0.293 \\
\hline 79 & 22.605 & 0.915 & 7.728 & 13.963 & 0.866 & 5.543 & 1.095 & 0.045 & 0.537 \\
\hline 80 & 0.006 & -0.989 & -0.386 & 0.000 & -1.000 & -6.820 & 10.906 & 0.832 & 0.791 \\
\hline 89 & 0.504 & -0.330 & 0.415 & 0.174 & -0.704 & -1.057 & 0.658 & -0.206 & 2.331 \\
\hline 92 & 0.899 & -0.053 & -0.122 & 1.633 & 0.240 & -0.012 & 1.757 & 0.275 & 0.031 \\
\hline 93 & 0.046 & -0.913 & 0.018 & 0.000 & -0.999 & -0.016 & 0.040 & -0.923 & 0.013 \\
\hline 97 & 0.183 & -0.690 & 0.026 & 0.006 & -0.988 & 0.002 & 0.001 & -0.999 & 0.000 \\
\hline
\end{tabular}


Textile and apparel sectors (codes 61, 62, and 67) also experienced significant and steady increases in comparative advantage from 2011 to 2017, with exports reaching \$752 million in 2016 (Reuters or Korea Trade-Investment Promotion Agency). Sector 61, knitted and crocheted apparel, exhibited a weak comparative advantage in 2011, but increased to a moderate advantage (RCA 2.6) by 2017. Sector 62, non-knitted apparel, was already strong in 2011 (RCA 10.9), but increased (RCA 19.88) by 2017. Sector 67, feathers and feather stuffing, increased from no comparative advantage in 2011 to a strong comparative advantage (RCA 10.49) in 2017. Increased comparative advantages in these sectors are significant, because they exhibited the strongest comparative advantage in 2017 and remain the only industry-based area showing a significant increase from 2011 to 2017. This indicates the type of early industrial development that may guide North Korea into economic development. Low wages and skilled workforce in the apparel industry have enabled this industry's export potential; moreover, exports of apparel industry products were also made possible due to the willingness of Chinese textile companies to subcontract orders from United States, Europe, Japan, South Korea, Canada, and Russia to North Korean textile factories, and subsequently deliver those orders with a "Made in China" label (Washington Post, 2017).

Between 2011 and 2017, the North Korean economy also exhibited steady comparative advantages in sector 26 (ore, slag, and ash) with an RCA of 8.3 in 2011, and an RCA of 8.3 in 2017 and 27 (mineral fuels, mineral oils, and products of their distillations) with an RCA of 2.1 in 2011 and an RCA of 1.9 in 2017. Most of the ore exports of North Korea is made up of iron ore exports, with revenue peaking at $\$ 415$ million in 2013, then declining to $\$ 187$ million in 2017 due to a reduction in global demand for iron ore. In 2013, North Korea surpassed Vietnam to become the world's number one exporter of anthracite coal, which is the highest ranked type of coal, generating $\$ 1.4$ billion in revenue (Pavone and Sun, 2014). A comparative advantage was found in coal exports through 2017 before exports were completely halted in order to put greater pressure on North Korea (Denyer, 2017).

Some metals and products made of those metals maintained comparative advantages: steel (72), lead (78), tin (80) and zinc (79). Steel (code 72) was the largest export sector in 2018, and maintained a comparative advantage from 2011 (RCA 2.3) to 2017 (RCA 1.9). Lead (code 78) had a weak comparative advantage in 2011 (RCA 1.3) that increased to a moderate comparative advantage in 2017 (RCA 3.1). Tin (code 80) increased from no comparative advantage in $2011(0.0)$ to a strong comparative advantage in 2017 (RCA 10.9). Zinc (code 79) lost its comparative advantage from 2011 (22.6) to 2017 (1.09). The other trade indices corroborate the comparative advantages indicated by RCA.

The findings of this analysis are cross validated. The three trade indices generally corroborate each other throughout Table 5, with few exceptions. This validates the comparative advantages exhibited in each sector. This study is exceptional in its use of three trade indices across several sectors. Although theoretically the results should indicate uniform results, it is still remarkable that the indices uniformly comply with each other throughout this study in practice. Regarding the use of all three indices, future studies should utilize these three indices together in order to continue to theoretically test the validity of each index, and to confirm comparative advantages in each sector.

Policymakers and practitioners must carefully examine export specialization when making decisions regarding trade and trade policy. Trade practitioners can see the trends in this data to note the most specialized sectors in North Korea for future trade. Investments in specialized sectors tend to be durable, especially when the long-term trends indicate increasing specialization. Policymakers need to utilize the results of this study as well. Export specialization can indicate which sectors a government needs to protect, and which sectors need to be bolstered through policy. 
Moreover, exceptionally savvy policymakers will harness trends in order to boost economic development. As a benchmark, South Korea and Malaysia invested in apparel industries early in economic development before diversifying to other areas (Athukorala and Narayanan, 2018 and Ha-Brookshire and Lee, 2010). This model is appropriate given North Korea's trade specialization in apparel. Dependence on natural resources may hinder economic development if not managed properly (Danish, Baloch, Mahmood and Zhang, 2019). Moreover, this research remains an important starting point for those interested in North Korea and trade. As a note of caution, comparative advantages are dynamic; with time, these advantages may diminish or strengthen. It will be necessary update this data and maintain current statistics. Policymakers and practitioners should be aware of this time limitation.

\section{CONCLUSION}

North Korea is a notoriously problematic country to study; however, this study manages to break through those challenges to provide an evocative analysis of its trade scenario and identify specialized trade sectors; moreover, this research provides valuable evidence for practitioners and policymakers. Trade practitioners are eager to trade with North Korea if the country opens its economy to the rest of the world; however, there remains little guidance on which sectors should be developed. This study provides guidance as to which sectors could prove to be most valuable for practitioners. Policymakers need to be able to make trade policies that protect and develop the country in the long-term; this research identifies specialized sectors that can lead to development and economic prosperity. Finally, this study distinctively uses three measures of comparative advantage to compare and contrast the results among the three indices; the results among the three indices remain remarkably stable, confirming the results of this study, and prescribing this method in future studies.

Multiple limitations remain for this study; firstly, North Korea's heavily sanctioned economy revealed the complexity of analyzing its trade position. Based on 2018 data and analysis, North Korea's trade specialization changed dramatically. It is likely that other sectors were distorted because of trade bans or sanctions before 2018; thus, the measured trade specialization likely does not represent how North Korea could be with no sanctions or bans. Indeed, most nations throughout the world have some level of trade distortion because of global trade policies; however, North Korea remains exceptional because of its isolationism. Academic contributions to the methods employed remain limited to a single country's data; additional data across many nations may find similar or contradictory results.

Future studies regarding North Korea would likely have mixed results regarding trade specialization depending on sanctions and trade bans. Many sectors were banned or heavily sanctioned in late 2017. If those bans continue, those sectors will likely become distorted; future studies can map those distortions. If the bans and sanctions are lifted it is likely that the results of this study would be corroborated by future studies. Given the dynamic nature of trade in North Korea it will be important to keep abreast to changes in policies. Studies measuring trade specialization in the future should consider this threefold method. It is possible that discrepancies could be more visible in other economies; moreover, this method and its results should be further tested across many nations.

Comparative advantages are dynamic. As the North Korean economy changes, comparative advantages will also change; thus, this research is time sensitive. It will be necessary to continuously review this data in order to monitor changes in comparative advantages. Some industries change more readily than others. It is likely that some comparative advantages will remain longer-term while others will dissipate more quickly. There is a continuous demand for this type of research. 


\section{REFERENCES}

Athukorala P. \& Narayanan, S. (2018). Economic corridors and regional development: The Malaysian experience. World Development. 106, 1-14.

Balassa, B., (1965). Trade liberalization and 'revealed' comparative advantage. The Manchester School of Economic and Social Studies. 32, 99-123.

Kim, B. E. Korean economy 'on the verge of possible deflation. (September 18, 2019). The Korea Times. Retrieved September 25, 2019, from https://www.koreatimes.co.kr/www/biz/2019/09/488_275767.html

Connel, J. (2019). Tourism as political theatre in North Korea. Political Geography. 68, 34-45.

Danish, Baloch, M. A., Mahmood, N. \& Zhang, J. W. "Effect of natural resources, renewable energy and economic development on CO2 emissions in BRICS countries", Science of the Total Environment. 678, 632-638.

Denyer, S. China suspends North Korean coal imports, striking at regime's financial lifeline. (February 18, 2017). The Washington Post. Retrieved September 16, 2019, from https://www.washingtonpost.com/world/ china-suspends-north-koreas-coal-imports-striking-at-regimes-financial-lifeline/2017/02/18/8390b0e6f5df-11e6-a9b0-ecee7ce475fc_story.html

Department of Defense (USA). (2019). Indo-Pacific Strategy Report. Retrieved September 2, 2019, from https:// media.defense.gov/2019/Jul/01/2002152311/-1/-1/1/DEPARTMENT-OF-DEFENSE-INDO-PACIFICSTRATEGY-REPORT-2019.PDF

Dibooglu, S. \& Cevik, E. I. (2016). The effect of North Korean threats on financial markets in South Korea and Japan. Journal of Asian Economics, 43, 18-26.

Fifield, A. Ban on North Korean clothing exports will hurt women the most, experts say. (2017). The Washington Post. Retrieved on September 24, 2019, from https://www.washingtonpost.com/world/ban-on-northkorean-clothing-exports-will-hurt-women-the-most-experts-say/2017/09/16/2a6ec716-995c-11e7-a5273573bd073e02_story.html.

Grzelczyk, V. (2014). New approaches to North Korean politics after reunification: The search for a common Korean identity. Communist and Post-Communist Studies, 47(2), 179-190.

Ha-Brookshire, J. E. and Lee, Y. (2010). Korean apparel manufacturing industry: Exploration from the industry life cycle perspective. Clothing and Textile Research Journal. 28(4), 279-294.

Ha, S. E. \& Jang, S. J. (2016). National identity in a divided nation: South Koreans' attitudes toward North Korean defectors and the reunification of two Koreas. International Journal of Intercultural Relations, 55, 109-119.

Haggard, S. \& Noland, M. (2009). Famine in North Korea redux? Journal of Asian Economics. 20(4), 384-395.

Haggard, S. \& Noland, M. (2010). Reform from Below: Behavioral and Institutional Change in North Korea. Journal of Economic Behavior and Organization. 73, 133-152.

Haggard, S. \& Noland, M. (2010). Sanctioning North Korea: The political economy of denuclearization and proliferation. Asian Survey. 50(3), 539-568.

Hinloopen, J. \& Marrewijk, C. van. (2008). Empirical relevance of the Hillman condition for revealed comparative advantage: 10 stylized facts. Applied Economics, 40, 2313-2328.

Jo, H. R. Moon faces daunting task to revive stalled nuke talks. (May 19, 2019). The Korea Herald. 19-May-2019. Retrieved September 26, 2019, from http://www.koreaherald.com/view.php?ud=20190519000126\&fbcli $\mathrm{d}=$ IwAR2DTY62FLTmqXvRq0mhQuLP-5xpSEkWVGuRHtNVemfTUuW2juCmcXwH33k

Jung, K. \& Dalton, B. (2006). Rhetoric versus reality for the women of North Korea: Mothers of the revolution. Asian Survey. 46(5), 744-769.

Jung, K., Dalton, B. \& Willis, J. (2018). From patriarchal socialism to grassroots capitalism: The role of female entrepreneurs in the transition of North Korea. Women's Studies International Forum. 68, 19-27.

Kim, V. Investing in resource-rich North Korea seems like a good idea - but businesses find there's a catch. (March 17, 2019). Los Angeles Times. Retrieved September 10, 2019, from https://www.latimes.com/ world/la-fg-north-korea-investment-03172019-story.html 
Kwon, H. \& Chung, B. H. (2012). North Korea: Beyond Charismatic Politics. Lanham, Maryland: Rowman and Littlefield Publishers.

Lafay, G. (1990). La Measure des avantages comparatifs reveles. Economie Prospective Internationale, 41, 27-43.

Lankov, A. Who owns North Korea's Businesses? (March 17, 2017). NK News. Retrieved September 2, 2019, from https://www.nknews.org/2017/03/who-owns-north-koreas-businesses/

Laursen, K. (2015). Revealed comparative advantage and the alternatives as measures of international specialization. Eurasian Business Review, 5(1), 99-115.

Lukin, A. \& Zakharova, L. (2018). Russia-North Korea Economic Ties: Is there more than meets the eye? Foreign Policy Research Institute Spring. pp. 244-261.

Ma, A. A fishing deal with China could be the reason North Korea 'ghost ships' are flooding Japan. (December 17, 2017). Business Insider. Retrieved September 9, 2019, from https://www.businessinsider.com/northkorea-china-fishing-rights-deal-could-be-reason-for-ghost-ships-2017-12

Manyin, M. E. \& Nanto, D. K. (2011). The Kaesong North-South Korean Industrial Complex. Congressional Research Service.

Nagai, O. North Korea Trade shrank significantly in 2018, Beijing says. (January 15 2019). Nikkei Asian Review. Retrieved September 2, 2019, from https://asia.nikkei.com/Politics/International-relations/North-Koreatrade-shrank-significantly-in-2018-Beijing-says

North Korea's nuclear programme: How advanced is it? (August 10, 2017). BBC News. Retrieved September 26, 2019, from https://www.bbc.com/news/world-asia-pacific-11813699

OECD. (2011). Globalization, Comparative Advantage and the Changing Dynamics of Trade. Paris: OECD.

Heckscher, E. F. \& Ohlin, B. (1991). Heckscher-Ohlin Trade Theory, translated, edited, and introduced by Harry Flam and M. June Flanders. Cambridge, Mass: MIT Press.

Pavone, G. A. \& Sun, J. A. (2014). Coal Diplomacy: The Political Economy of North Korean Coal. Cambridge, Mass.: Harvard University.

Porter, M. E., (1980). Competitive Strategy: Techniques for Analyzing Industries and Competitors. New York: Free Press.

Reyes, G. U. (2014). Examining the Revealed Comparative Advantage of the ASEAN 6 Countries Using the Balassa Index and Lafay Index. Journal of Global Business and Trade. 10(1), 1-11.

Ricardo, D. (1817). On the Principles of Political Economy and Taxation. London: John Murray.

Rossato, F. G. F. S., Susaeta, A. Adams, D. C., Hidalgo, I. G., Araujo, T. D. A. \& Queiroz, A. (2018). Comparison of revealed comparative advantage indexes with application to trade tendencies of cellulose production from planted forests in Brazil, Canada, China, Sweden, Finland, and the United States. Forest Policy and Economics, 97, 59-66.

Salam, M. \& Haag, M. Atocities under Kim Jong-un: Indoctrination, Prison Gulags, Executions. (June 11, 2018). The New York Times. Retrieved September 2, 2019, from https://www.nytimes.com/2018/06/11/world/ asia/north-korea-human-rights.html

Security Council Tightens Sanctions on Democratic People's Republic of Korea, Unanimously Adopting Resolution 2397 (December 22, 2017). Meetings Coverage and Press Releases United Nations. Retrieved September 22, 2019, from https://www.un.org/press/en/2017/sc13141.doc.htm

Shimbun, Y. North Korea has violated UN sanctions by selling fishing rights to China. (January 31, 2019). The Straits Times. Retrieved September, 21 2019, from https://www.straitstimes.com/asia/east-asia/northkorea-has-violated-un-sanctions-by-selling-fishing-rights-to-china

Smith, A. (1776). An inquiry into the nature and causes of the wealth of nations. London: Strahan and Cadell.

Snyder, S. A. Where does the Russia-North Korea Relationship Stand? (April 29, 2019). Council on Foreign Relations. Retrieved September 2, 2019, from https://www.cfr.org/article/where-does-russia-north-korearelationship-stand

Song, J. A. \& Kang, B.S. Seoul risks rift with US over North Korean industrial zone. (March 21, 2019). Financial Times. Retrieved September 21, 2019, from https://www.ft.com/content/4971a95a-46b5-11e9-a965-23d669740bfb 
UNIDO. (1986). International comparative advantage in manufacturing: Changing profiles of resources and Trade. UNIDO Publication Sales No. E86 II B9. Vienna: United Nations Industrial Development Organization.

Vollrath, T. H. (1991). A theoretical evaluation of alternative trade intensity measures of revealed comparative advantage. Weltwirtschaftliches Archiv. 127, 265-280.

Weak South Korean economy and cooling North Korea ties threatening Moon Jae-in's political future. (April 27, 2019). The Japan Times. Retrieved September 26, 2019, from https://www.japantimes.co.jp/ news/2019/04/27/business/economy-business/weak-south-korean-economy-cooling-north-korea-tiesthreatening-moon-jae-ins-political-future/\#.XOtNVohKjIU

Winstanley-Chesters, R. (2018). Rare earth minerals, technology metals, and extractive landscapes in North Korea's web of political life. The Extractive Industries and Society. 5(1), 44-51.

Yeats, A. J. (1985). On the appropriate interpretation of the revealed comparative advantage index: implications of a methodology based on industry sector analysts. Weltwirtschaftilches Archiv. 121, 61-73.

Zakharova, L. (2016). Economic cooperation between Russia and North Korea: New goals and new approaches. Journal of Eurasian Studies. 7, 151-161. 


\section{ANALIZA SEVERNOKOREJSKOG TRGOVANJA U USLOVIMA ZAGREJANIH ODNOSA U SVETU - UZ UPOTREBU RCA, RSCA I TBI INDEKSA}

\section{Rezime:}

Na osnovu sastanaka na visokom nivou sa južnokorejskim i američkim liderima, denuklearizacija Severne Koreje i globalna ekonomska saradnja se čini dostižnom. Imajući u vidu takve pomake, ovaj rad želi da naglasi mogućnosti u okviru trgovinske politike za Severnu Koreju. Ovo istraživanje ukratko opisuje međunarodnu trgovinu u Severnoj Koreji i identifikuje ekonomske sektore koji su spremni da pospeše dalji razvoj ekonomije u Severnoj Koreji. Koristeći tri mere trgovinske specijalizacije - RCA, RSCA i TBI, ovaj rad analizira podatke o trgovini u vremenskom periodu od 2011. do 2018. Godine, kako bi se otkrili specijalizovani izvozni sektori u Severnoj Koreji. Zabrane na izvoz od strane Kine i zemalja članica Evropske Unije posebno štetno utiču na izvoz iz Severne Koreje na osnovu podataka za 2018. godinu. Severna Koreja ima komparativne prednosti u nekoliko sektora: ugalj, ribarstvo i odeća, između ostalog. Rast trgovine u Severnoj Koreji doveo bi do brze industrijalizacije i razvoja ako se zemlja otvori u oblasti ekonomije; dobro vođen pristup služio bi usmeravanju razvoja u određenim sektorima bez žrtvovanja drugih; Štaviše, ovo istraživanje savetuje koji sektori se mogu koristiti za razvoj Severne Koreje u ranoj fazi otvorenosti.

\section{Ključne reči:}

Severna Koreja, međunarodno trgovanje, RCA,

RSCA, TBI. 